\title{
Sphingomonas glacialis sp. nov., a psychrophilic bacterium isolated from alpine glacier cryoconite
}

Correspondence

Rosa Margesin

Rosa.Margesin@uibk.ac.at

\author{
De-Chao Zhang, ${ }^{1}$ Hans-Jürgen Busse, ${ }^{2}$ Hong-Can Liu, ${ }^{3}$ Yu-Guang Zhou, ${ }^{3}$ \\ Franz Schinner ${ }^{1}$ and Rosa Margesin ${ }^{1}$
}

\author{
${ }^{1}$ Institute of Microbiology, University of Innsbruck, Technikerstrasse 25, A-6020 Innsbruck, Austria \\ ${ }^{2}$ Institute of Bacteriology, Mycology and Hygiene, University of Veterinary Medicine Vienna, \\ Veterinärplatz 1, A-1210 Vienna, Austria \\ ${ }^{3}$ China General Microbiological Culture Collection Center and State Key Laboratory of Microbial \\ Resources, Institute of Microbiology, Chinese Academy of Sciences, Beijing 100101, PR China
}

\begin{abstract}
A non-motile, rod-shaped, yellow bacterium, designated $\mathrm{C}_{16 \mathrm{y}^{\top}}$, was isolated from alpine glacier cryoconite. Cells behaved Gram-positively, were aerobic and psychrophilic (good growth at 1$25^{\circ} \mathrm{C}$ ). Phylogenetic analysis based on 16S rRNA gene sequences showed that strain $\mathrm{C} 16 \mathrm{y}^{\top}$ was related to the genus Sphingomonas and had highest 16S rRNA gene sequence similarity with Sphingomonas oligophenolica JCM $12082^{\top}(97.6 \%)$ and Sphingomonas echinoides DSM $1805^{\top}(97.2 \%)$. DNA-DNA hybridization demonstrated that strain $\mathrm{C}^{\top 6 \mathrm{y}^{\top}}$ could not be considered as a member of either Sphingomonas oligophenolica or Sphingomonas echinoides. Strain $\mathrm{C}_{16}{ }^{\top}$ contained $\mathrm{Q}-10$ as the predominant ubiquinone and $\mathrm{C}_{18: 1}$ and $\mathrm{C}_{16: 0}$ were the dominant fatty acids. The polar lipid profile contained phosphatidylglycerol, diphosphatidylglycerol, phosphatidylethanolamine, sphingoglycolipid, five unidentified glycolipids, two unidentified aminophospholipids and two unidentified lipids. The major polyamines were the triamines sym-homospermidine and spermidine. The $\mathrm{G}+\mathrm{C}$ content was $67.9 \mathrm{~mol} \%$. Combined data from phenotypic, phylogenetic and DNA-DNA relatedness studies demonstrated that strain $\mathrm{C}_{16} \mathrm{y}^{\top}$ is a representative of a novel species of the genus Sphingomonas, for which we propose the name Sphingomonas glacialis sp. nov. The type strain is $\mathrm{C}_{16 y^{\top}}\left(=\mathrm{DSM} 22294^{\top}=\mathrm{CGMCC}\right.$ $1.8957^{\top}=\operatorname{CIP} 110131^{\top}$ ).
\end{abstract}

The genus Sphingomonas was first proposed by Yabuuchi et al. (1990), who described five species and two genospecies. On the basis of phylogenetic, chemotaxonomic and physiological analyses, the genus Sphingomonas has been divided into four genera: Sphingomonas, Sphingobium, Novosphingobium and Sphingopyxis (Takeuchi et al., 2001). These genera differ in their polyamine pattern, nucleotide signatures and some phenotypic characteristics (e.g. nitrate reduction) and form four $16 \mathrm{~S}$ rRNA gene sequence clusters (I-IV) with distance matrix analysis (Takeuchi et al., 2001). However, Yabuuchi et al. (2002) emphasized that the three genera, Sphingobium, Novosphingobium and Sphingopyxis, should be considered as later homotypic synonyms of species of the genus Sphingomonas because there was no phenotypic and phylogenetic evidence to support their proposal. So far, the nomenclature of Takeuchi et al. (2001) is generally used (Busse et al., 2003). At the time of

The GenBank/EMBL/DDBJ accession number for the 16S rRNA gene sequence of strain $\mathrm{C} 16 \mathrm{y}^{\top}$ is GQ253122.

A supplementary figure and a supplementary table are available with the online version of this paper. writing, the genus Sphingomonas sensu stricto contains 45 species with validly published names. According to emended descriptions (Takeuchi et al., 2001; Yabuuchi et al., 2002; Busse et al., 2003), this genus accommodates aerobic, Gram-stain negative and non-spore-forming bacteria that are characterized chemotaxonomically by the absence of 3-hydroxy fatty acids and by the presence of 2-hydroxymyristic acid $\left(\mathrm{C}_{14: 0} 2-\mathrm{OH}\right), \mathrm{Q}-10$ as the respiratory quinone and sym-homospermidine as the key polyamine.

Strain $\mathrm{C}_{16} \mathrm{y}^{\mathrm{T}}$ was isolated from an alpine glacier cryoconite collected from the Stubai Glacier near Innsbruck in Tyrol, Austria (altitude $2900 \mathrm{~m}$ ). The strain was isolated as described previously (Margesin et al., 2002). Strain $\mathrm{C}_{16} \mathrm{y}^{\mathrm{T}}$ was routinely cultured on R2A agar (containing $0.05 \%$ yeast extract, $0.05 \%$ peptone, $0.05 \%$ Casamino acids, $0.05 \%$ glucose, $0.05 \%$ starch, $0.03 \%$ sodium pyruvate, $0.03 \% \quad \mathrm{~K}_{2} \mathrm{HPO}_{4}, \quad 0.005 \% \quad \mathrm{MgSO}_{4}, \quad 1.5 \%$ agar; $\mathrm{pH} \quad 7$; Reasoner \& Geldreich, 1985) at $20{ }^{\circ} \mathrm{C}$ and stored as a suspension in skimmed milk $\left(10 \%\right.$, w/v) at $-80{ }^{\circ} \mathrm{C}$. Sphingomonas echinoides DSM $1805^{\mathrm{T}}$ and Sphingomonas 
oligophenolica JCM $12082^{\mathrm{T}}$ were routinely grown on R2A agar at $25{ }^{\circ} \mathrm{C}$ and used as reference strains.

DNA was extracted and purified as described by Sambrook et al. (1989). The gene encoding $16 \mathrm{~S}$ rRNA was amplified by PCR with two universal primers (Zhang et al., 2006). PCR products were cloned using the PGEM-T easy vector system (Promega). Sequencing reactions were performed as described by Zhang et al. (2006). Phylogenetic analysis carried out by using the program MEGA version 3.0 (Kumar et al., 2004) showed that strain C16y ${ }^{\mathrm{T}}$ was grouped with the members of the genus Sphingomonas and formed a distinct cluster with Sphingomonas oligophenolica JCM $12082^{\mathrm{T}}$ (97.6\%) and Sphingomonas echinoides DSM $1805^{\mathrm{T}}(97.2 \%)$ in the neighbour-joining tree (Fig. 1). In addition, a similar tree topology was also found in the tree generated with the maximum-likelihood method in the PHYLIP 3.69 package (Felsenstein, 2009) after sequences were aligned using CLUSTAL x 1.8 (Thompson et al.,1997). Nucleogide signatures specific to the 16S rRNA of strain C16y ${ }^{\mathrm{T}}$ were 52:359 (C-G), $134(\mathrm{~A}), 593(\mathrm{G}), 987: 1218(\mathrm{G}-$ C) and $990: 1215(\mathrm{U}-\mathrm{G})$, which are the same as those of the genus Sphingomonas (Cluster 1) reported by Takeuchi et al. (2001) except that there was A instead of G at position 134 (Escherichia coli numbering; Brosius et al., 1978).

Cell morphology was examined by phase-contrast microscopy ( $\times 1000$; Leitz Diaplan). Cell motility was evaluated on soft agar at the DSMZ, Braunschweig, Germany. Gramreaction was tested by classical Gram-staining and was confirmed by $\mathrm{KOH}$ lysis. Catalase activity was determined by bubble production in $3 \%(\mathrm{v} / \mathrm{v}) \mathrm{H}_{2} \mathrm{O}_{2}$ and oxidase activity was determined using $1 \%(\mathrm{w} / \mathrm{v}) \quad N, N, N^{\prime}, N^{\prime}-$ tetramethyl-p-phenylenediamine. Physiological and biochemical characteristics and enzyme activities were determined with the API $20 \mathrm{E}$, API $20 \mathrm{NE}$ and API ZYM systems (bioMérieux) at $25{ }^{\circ} \mathrm{C}$. $\quad \beta$-Galactosidase, esterase lipase (C8), amylase and protease activities were also tested on R2A agar supplemented with the appropriate substrates (Margesin et al., 2003). Growth at $1-42{ }^{\circ} \mathrm{C}$ was assessed on R2A agar and in R2A broth at 150 r.p.m. Growth at pH 59 and with $0-5 \%(\mathrm{w} / \mathrm{v}) \mathrm{NaCl}$ was determined on R2A agar. Susceptibility to antibiotics was determined on R2A agar supplemented with various antibiotics and incubated at $25{ }^{\circ} \mathrm{C}$. All tests were carried out simultaneously with strain $\mathrm{C} 6 \mathrm{y}^{\mathrm{T}}$ and the two reference strains. The morphological, physiological and biochemical characteristics of strain $\mathrm{C} 16 \mathrm{y}^{\mathrm{T}}$ are given in the species description and the features that differentiate strain $\mathrm{C} 16 \mathrm{y}^{\mathrm{T}}$ from the reference strains are given in Table 1.

The respiratory quinones were extracted and purified according to Collins (1985) and were analysed by HPLC (Wu et al., 1989), using Q-10 from Sphingomonas oligophenolica JCM $12082^{\mathrm{T}}$ as a reference. The predominant ubiquinone of strain $\mathrm{C} 16 \mathrm{y}^{\mathrm{T}}$ was Q-10. For fatty acid methyl ester analysis, strain $\mathrm{C} 16 \mathrm{y}^{\mathrm{T}}$ and the reference strains were grown on $\mathrm{R} 2 \mathrm{~A}$ agar at $20{ }^{\circ} \mathrm{C}$ for 3 days. The fatty acid methyl esters were extracted and prepared according to the standard protocol of the Microbial Identification system (Sasser, 1990). The predominant cellular fatty acids ( $>5 \%)$ of strain $\mathrm{C}_{16} \mathrm{y}^{\mathrm{T}}$ were summed feature 7 (comprising one or more of $\mathrm{C}_{18: 1} \omega 7 c, \mathrm{C}_{18: 1} \omega 9 t$ and $\mathrm{C}_{18: 1}(\omega 12 t, 61.4 \%), \mathrm{C}_{16: 0}$ $\left(8.2 \%\right.$ ), summed feature 4 (comprising $\mathrm{C}_{16: 1} \omega 7 c$ and/or iso- $\left.\mathrm{C}_{15: 0} \quad 2-\mathrm{OH} ; \quad 6.8 \%\right)$ and $\mathrm{C}_{14: 0} \quad 2-\mathrm{OH} \quad(5.9 \%)$ (Supplementary Table S1, available in IJSEM Online). The fatty acid profile of strain $\mathrm{C}_{16} \mathrm{y}^{\mathrm{T}}$ was in agreement with those of other members of the genus Sphingomonas (Denner et al., 1999; Busse et al., 2003; Ohta et al., 2004; Busse et al., 2005).

The cellular polar lipids were extracted and analysed on silica gel plates (Kieselgel $60 \mathrm{~F}$; Merck) by TLC (Kates, 1986). Ethanolic molybdatophosphoric acid, $\alpha$-naphtholsulphuric acid reagent, Dragendorff reagent, ninhydrin and molybdenum blue reagent were used for the detection of total lipids, glycolipids, quaternary nitrogen and aminophospholipids, respectively. The polar lipid profile contained phosphatidylglycerol, diphosphatidylglycerol, phosphatidylethanolamine, sphingoglycolipid, five unidentified glycolipids, two unidentified aminophospholipids and two unidentified lipids (Supplementary Fig. S1). Although the polar lipids of the type strains of both Sphingomonas echinoides and Sphingomonas oligophenolica have been analysed (Denner et al., 1999; Ohta et al., 2004), only the polar lipid profile of Sphingomonas echinoides DSM $1805^{\mathrm{T}}$ was accessible for visual comparison. The polar lipid profiles of Sphingomonas echinoides DSM $1805^{\mathrm{T}}$ and $\mathrm{C} 16 \mathrm{y}^{\mathrm{T}}$ exhibited some striking differences. The polar lipid profile of strain $\mathrm{C} 16 \mathrm{y}^{\mathrm{T}}$ did not contain the lipids L1 and PL1 of Sphingomonas echinoides DSM $1805^{\mathrm{T}}$ and the lipids GL1, GL5 and L2 of strain C16y ${ }^{\mathrm{T}}$ also distinguished it from Sphingomonas echinoides DSM $1805^{\mathrm{T}}$.

For polyamine analysis, strain $\mathrm{C}^{16 \mathrm{y}^{\mathrm{T}}}$ was grown in PYE medium (containing $0.3 \%$ yeast extract, $0.3 \%$ peptone; $\mathrm{pH} 7$ ) at $20{ }^{\circ} \mathrm{C}$. Polyamines were extracted as described by Busse \& Auling (1988) and analysed as described by Busse et al. (1997) using the HPLC equipment reported by Stolz et al. (2007). The polyamine pattern of strain $\mathrm{C} 16 \mathrm{y}^{\mathrm{T}}$ consisted of $\left.[\mu \mathrm{mol} \text { (g dry mass })^{-1}\right]$ sym-homospermidine (38.9), spermidine (13.0), spermine (3.4), 1,3-diaminopropane (1.6) and putrescine (0.5). The presence of symhomospermidine as a major compound in the polyamine pattern has been considered as a diagnostic feature of the genus Sphingomonas (Busse et al., 1999; Takeuchi et al., 2001), and species recently assigned to this genus also share this trait (Busse et al., 2003, 2005; Xie \& Yokota, 2006; Kämpfer et al., 2007; Huang et al., 2009; Roh et al., 2009; Nigam et al., 2010; Zhang et al., 2010). However, it has been reported that species of the related genus Sphingosinicella also contain sym-homospermidine as the major compound (Geueke et al., 2007) in the polyamine pattern, which hampers the classification of novel strains within this family.

The DNA G $+\mathrm{C}$ content was determined using the thermal denaturation method with E. coli $\mathrm{K}-12$ as reference. 


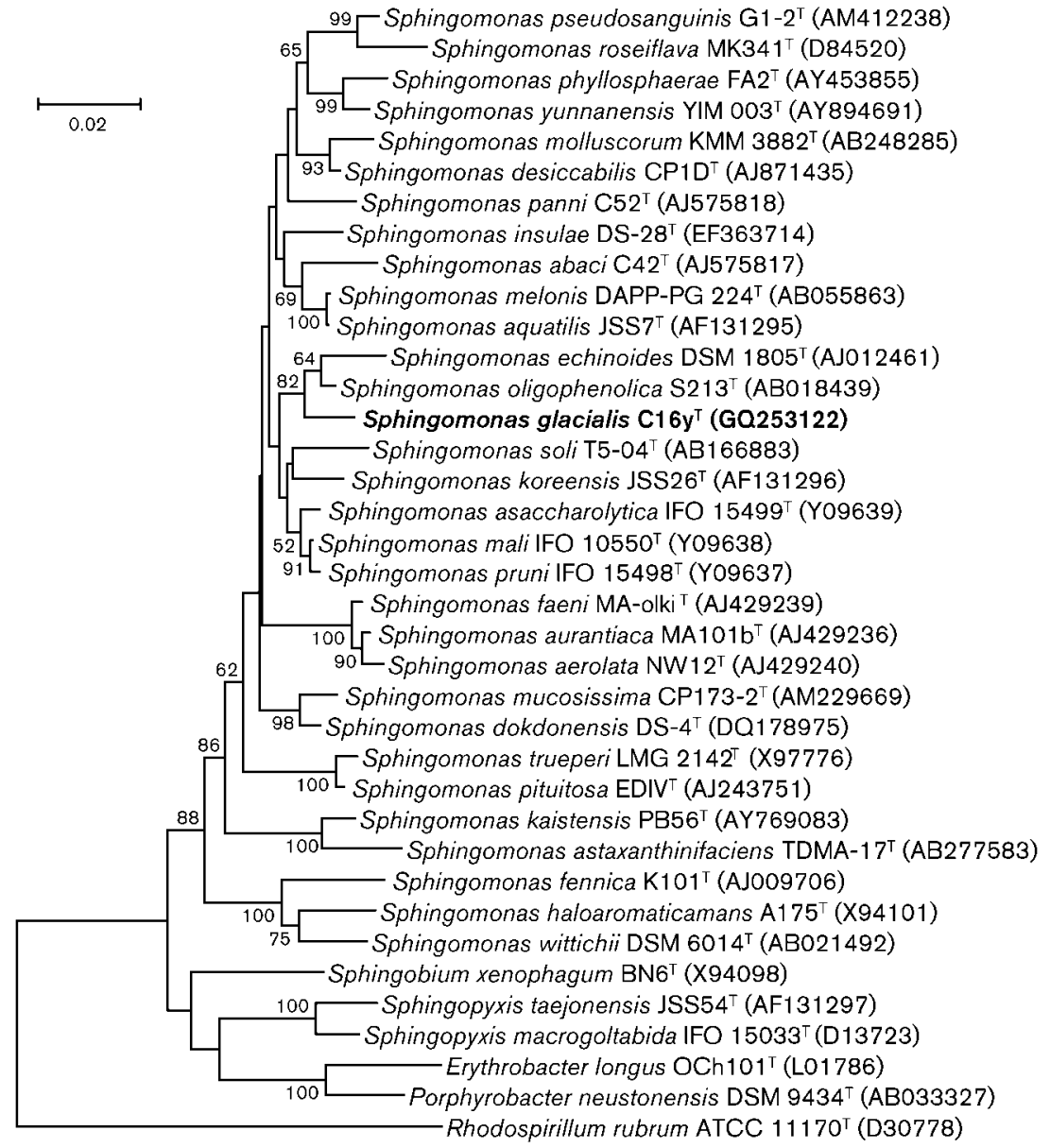

Fig. 1. Neighbour-joining tree, based on $16 \mathrm{~S}$ rRNA gene sequences, showing the phylogenetic positions of strain $\mathrm{C}_{16 y^{\top}}$, some members of the genus Sphingomonas and representatives of other related taxa. Bootstrap values $(50 \%)$ based on 1000 replicates are shown at branch nodes. Bar, $2 \%$ sequence divergence.
DNA-DNA hybridization was done using the liquid renaturation method (De Ley et al., 1970) as modified by Huß et al. (1983). Both experiments were carried out using a Lambda 35 UV/VIS spectrometer equipped with a temperature program controller (PerkinElmer). The DNA $\mathrm{G}+\mathrm{C}$ content of strain $\mathrm{C} 16 \mathrm{y}^{\mathrm{T}}$ was $67.9 \mathrm{~mol} \%$. DNA-DNA relatedness between strain $\mathrm{C} 16 \mathrm{y}^{\mathrm{T}}$ and Sphingomonas oligophenolica JCM $12082^{\mathrm{T}}$ and Sphingomonas echinoides DSM $1805^{\mathrm{T}}$ were $23.0 \%$ and $19.5 \%$, respectively, which were much lower than the $70 \%$ DNA-DNA relatedness threshold that is recommended for species demarcation (Wayne et al., 1987), thus verifying that the isolate represented a species different to Sphingomonas oligophenolica and Sphingomonas echinoides.

The data presented above demonstrate that strain $\mathrm{C} 16 \mathrm{y}^{\mathrm{T}}$ is a psychrophilic member of the genus Sphingomonas. Strain $\mathrm{C} 16 \mathrm{y}^{\mathrm{T}}$ could be easily differentiated from its closest phylogenetic neighbours, Sphingomonas oligophenolica JCM $12082^{\mathrm{T}}$ and Sphingomonas echinoides DSM $1805^{\mathrm{T}}$, by its inability to produce $N$-acetyl- $\beta$-glucosaminidase, its weak growth at $30{ }^{\circ} \mathrm{C}$ and the relative amounts of $\mathrm{C}_{14: 0} 2$ $\mathrm{OH}$ and summed feature 4 . In addition, strain $\mathrm{C} 16 \mathrm{y}^{\mathrm{T}}$ could be easily differentiated from Sphingomonas oligophenolica JCM $12082^{\mathrm{T}}$ by its inability to reduce nitrate and hydrolyse gelatin, the absence of $\alpha$-fucosidase and its ability to assimilate D-glucose and maltose, to grow with $1 \%(\mathrm{w} / \mathrm{v})$ $\mathrm{NaCl}$ and to tolerate penicillin $\mathrm{G}\left(30-100 \mu \mathrm{g} \mathrm{ml}^{-1}\right)$ and ampicillin $\left(30 \mu \mathrm{g} \mathrm{ml}{ }^{-1}\right)$. Strain $\mathrm{C} 16 \mathrm{y}^{\mathrm{T}}$ could be distinguished from Sphingomonas echinoides DSM $1805^{\mathrm{T}}$ on the basis of absence and presence of certain lipids, its ability to hydrolyse Tween 80 , its inability to assimilate gluconate, its lower resistance to ampicillin and its immotility. Therefore, on the basis of phenotypic, phylogenetic and genomic evidence, strain $\mathrm{C}_{16} \mathrm{y}^{\mathrm{T}}$ is a representative of a novel species of the genus Sphingomonas, for which the name Sphingomonas glacialis sp. nov. is proposed.

\section{Description of Sphingomonas glacialis sp. nov.}

Sphingomonas glacialis (gla.cia'lis. L. fem. adj. glacialis referring to the frozen, icy environment from which the type strain was isolated).

Cells are aerobic, Gram-negative, non-motile, short rods $\left(0.5 \times 0.8 \mu \mathrm{m}\right.$ after 6 days at $20{ }^{\circ} \mathrm{C}$ on R2A agar $)$. Colonies on R2A agar are yellow (orange after approx.14 days), convex and round with entire margins $(2 \mathrm{~mm}$ in diameter after 6 days at $20{ }^{\circ} \mathrm{C}$ ). Grows well at $1-25^{\circ} \mathrm{C}$ and weakly at $30{ }^{\circ} \mathrm{C}$ (in R2A broth, biomass at $30{ }^{\circ} \mathrm{C}$ is about one-third of that produced at $1-25^{\circ} \mathrm{C}$ ) and does not grow at $37{ }^{\circ} \mathrm{C}$. 
Table 1. Phenotypic characteristics that differentiate strain $\mathrm{C} 16 \mathrm{y}^{\top}$ from its closest phylogenetic neighbours

Strains: 1, Sphingomonas glacialis sp. nov. ${\mathrm{C} 16 \mathrm{y}^{\mathrm{T}}}^{\mathrm{T}} ; 2$, S. oligophenolica JCM $12082^{\mathrm{T}}$; 3, S. echinoides DSM $1805^{\mathrm{T}}$. Data were taken from this study. All strains are positive for aesculin hydrolysis, oxidase, alkaline phosphatase, acid phosphatase, cystine arylamidase, leucine arylamidase, valine arylamidase, naphthol-AS-BI-phosphohydrolase and $\alpha$ glucosidase. All strains are negative for indole production, glucose fermentation, lipase (C14), arginine dihydrolase, amylase, urease, $\alpha$ mannosidase, assimilation of D-mannose, D-mannitol, trisodium citrate, adipic acid, capric acid and phenylacetic acid and resistance to $\left(\mu \mathrm{g} \mathrm{ml}^{-1}\right)$ chloramphenicol (100), kanamycin (30), rifampicin (30) and tetracycline $(30) .+$, Positive; $\mathrm{w}$, weakly positive; -, negative.

\begin{tabular}{|c|c|c|c|}
\hline Characteristic & 1 & 2 & 3 \\
\hline Motility & - & - & + \\
\hline Growth at $30{ }^{\circ} \mathrm{C}$ & $\mathrm{w}$ & + & + \\
\hline Growth with $1 \%(\mathrm{w} / \mathrm{v}) \mathrm{NaCl}$ & + & - & + \\
\hline Nitrate reduction & - & + & - \\
\hline \multicolumn{4}{|l|}{ Hydrolysis of: } \\
\hline Gelatin & - & + & - \\
\hline Tween 80 & + & + & - \\
\hline \multicolumn{4}{|l|}{ Enzymes (API ZYM) } \\
\hline$N$-Acetyl- $\beta$-glucosaminidase & - & + & + \\
\hline$\alpha$-Fucosidase & - & + & - \\
\hline \multicolumn{4}{|l|}{ Assimilation of (API $20 \mathrm{NE}$ ): } \\
\hline D-Glucose & + & - & + \\
\hline Maltose & + & - & + \\
\hline Malic acid & $\mathrm{w}$ & - & w \\
\hline Gluconate & - & w & + \\
\hline \multicolumn{4}{|l|}{ Resistance to $\left(\mu \mathrm{g} \mathrm{ml}^{-1}\right)$ : } \\
\hline Ampicillin (30) & + & - & + \\
\hline Ampicillin (100) & - & - & + \\
\hline Penicillin G $(30-100)$ & + & - & + \\
\hline Streptomycin $(100)$ & $\mathrm{w}$ & - & + \\
\hline
\end{tabular}

Grows at $\mathrm{pH} 7-8$ and with $0-1 \%(\mathrm{w} / \mathrm{v}) \mathrm{NaCl}$. Positive for catalase and cytochrome $c$ oxidase. Negative for nitrate reduction, indole production, $\mathrm{H}_{2} \mathrm{~S}$ production and urease. Positive for aesculin hydrolysis, alkaline phosphatase, acid phosphatase, esterase (C4; weak) esterase lipase (C8), cystine arylamidase, leucine arylamidase, valine arylamidase, trypsin, $\alpha$-chymotrypsin (weak), naphthol-AS-BIphosphohydrolase, $\alpha$ - and $\beta$-glucosidase, $\beta$-galactosidase, $\beta$-glucuronidase. Negative for lipase (C14), gelatinase, arginine dihydrolase, lysine dihydrolase, ornithine dihydrolase, tryptophan deaminase, $N$-acetyl- $\beta$-glucosaminidase, $\alpha$-fucosidase and $\alpha$-mannosidase. Assimilates Larabinose, D-glucose, maltose and malic acid (weakly) but does not assimilate D-mannose, D-mannitol, citrate, potassium gluconate, adipic acid, capric acid or phenylacetic acid. Does not ferment L-arabinose, D-glucose, melibiose, L-rhamnose, sucrose, inositol, D-mannitol, sorbitol or amygdalin. Resistant to $\left(\mu \mathrm{g} \mathrm{ml}{ }^{-1}\right)$ ampicillin (30), penicillin G (100) and streptomycin (30) and sensitive to ampicillin (100), chloramphenicol (30), kanamycin (30), rifampicin (30) and tetracycline (30).
The predominant cellular fatty acids $(>5 \%)$ are summed feature 7 (comprising one or more of $\mathrm{C}_{18: 1} \omega 7 c, \mathrm{C}_{18: 1} \omega 9 t$ and $\left.\mathrm{C}_{18: 1} \omega 12 t\right), \mathrm{C}_{16: 0}$, summed feature 4 (comprising $\mathrm{C}_{16: 1} \omega 7 c$ and/or iso- $\left.\mathrm{C}_{15: 0} 2-\mathrm{OH}\right)$ and $\mathrm{C}_{14: 0} 2-\mathrm{OH}$. The predominant ubiquinone is $\mathrm{Q}-10$. The polar lipid profile contains phosphatidylglycerol, diphosphatidylglycerol, phosphatidylethanolamine, sphingoglycolipid, five unidentified glycolipids, two unidentified aminophospholipids and two unidentified lipids. The polyamine pattern contains major amounts of sym-homospermidine and relatively high amounts of spermidine. The DNA G+C content of the type strain is $67.9 \mathrm{~mol} \%$.

The type strain, $\mathrm{C}_{16 \mathrm{y}^{\mathrm{T}}}\left(=\mathrm{DSM} 22294^{\mathrm{T}}=\right.$ CGMCC $1.8957^{\mathrm{T}}$ $=$ CIP $11013^{\mathrm{T}}$ ), was isolated from a glacier cryoconite collected from the Stubai Glacier, Austria.

\section{Acknowledgements}

We thank P. Thurnbichler and J. Mair for technical assistance and Dr Hiroyuki Ohta for providing us with the type strain of Sphingomonas oligophenolica.

\section{References}

Brosius, J., Palmer, M. L., Kennedy, P. J. \& Noller, H. F. (1978). Complete nucleotide sequence of a $16 \mathrm{~S}$ ribosomal RNA gene from Escherichia coli. Proc Natl Acad Sci U S A 75, 4801-4805.

Busse, H.-J. \& Auling, G. (1988). Polyamine pattern as a chemotaxonomic marker within the Proteobacteria. Syst Appl Microbiol 11, 1-8.

Busse, H.-J., Bunka, S., Hensel, A. \& Lubitz, W. (1997). Discrimination of members of the family Pasteurellaceae based on polyamine patterns. Int J Syst Bacteriol 47, 698-708.

Busse, H.-J., Kämpfer, P. \& Denner, E. B. (1999). Chemotaxonomic characterisation of Sphingomonas. J Ind Microbiol Biotechnol 23, 242-251.

Busse, H.-J., Denner, E. B. M., Buczolits, S., Salkinoja-Salonen, M., Bennasar, A. \& Kämpfer, P. (2003). Sphingomonas aurantiaca sp. nov., Sphingomonas aerolata sp. nov. and Sphingomonas faeni sp. nov., air- and dustborne and Antarctic, orange-pigmented, psychrotolerant bacteria, and emended description of the genus Sphingomonas. Int $J$ Syst Evol Microbiol 53, 1253-1260.

Busse, H.-J., Hauser, E. \& Kämpfer, P. (2005). Description of two novel species, Sphingomonas abaci sp. nov. and Sphingomonas panni sp. nov. Int J Syst Evol Microbiol 55, 2565-2569.

Collins, M. D. (1985). Isoprenoid quinone analysis in classification and identification. In Chemical Methods in Bacterial Systematics, pp. 267-287. Edited by M. Goodfellow \& D. E. Minnikin. London: Academic Press.

De Ley, J., Cattoir, H. \& Reynaerts, A. (1970). The quantitative measurement of DNA hybridization from renaturation rates. Eur $J$ Biochem 12, 133-142.

Denner, E. B. M., Kämpfer, P., Busse, H.-J. \& Moore, E. R. B. (1999), Reclassification of Pseudomonas echinoides Heumann 1962, 343 ${ }^{\mathrm{AL}}$, in the genus Sphingomonas as Sphingomonas echinoides comb. nov. Int $J$ Syst Bacteriol 49, 1103-1109.

Felsenstein, J. (2009). PHYLIP (phylogeny inference package) version 3.69. Distributed by the author. Department of Genome Sciences, University of Washington, Seattle, USA.

Geueke, B., Busse, H.-J., Fleischmann, T., Kämpfer, P. \& Kohler, H.-P. E. (2007). Description of Sphingosinicella xenopeptidilytica sp. 
nov., a $\beta$-peptide-degrading species, and emended descriptions of the genus Sphingosinicella and the species Sphingosinicella microcystinivorans. Int J Syst Evol Microbiol 57, 107-113.

Huang, H.-D., Wang, W., Ma, T., Li, G.-O., Liang, F.-L. \& Liu, R.-L. (2009). Sphingomonas sanxanigenens sp. nov., isolated from soil. Int J Syst Evol Microbiol 59, 719-723.

Huß, V. A. R., Festl, H. \& Schleifer, K. H. (1983). Studies on the spectrophotometric determination of DNA hybridization from renaturation rates. Syst Appl Microbiol 4, 184-192.

Kämpfer, P., Meurer, U., Esser, M., Hirsch, T. \& Busse, H.-J. (2007). Sphingomonas pseudosanguinis sp. nov., isolated from the water reservoir of an air humidifier. Int J Syst Evol Microbiol 57, 1342-1345.

Kates, M. (1986). Techniques of Lipidology, 2nd edn. Amsterdam: Elsevier.

Kumar, S., Tamura, K. \& Nei, M. (2004). MEGA3: integrated software for molecular evolutionary genetics analysis and sequence alignment. Brief Bioinform 5, 150-163.

Margesin, R., Zacke, G. \& Schinner, F. (2002). Characterization of heterotrophic microorganisms in alpine glacier cryoconite. Arct Antarct Alp Res 34, 88-93.

Margesin, R., Gander, S., Zacke, G., Gounot, A. M. \& Schinner, F. (2003). Hydrocarbon degradation and enzyme activities of coldadapted bacteria and yeasts. Extremophiles 7, 451-458.

Nigam, A., Jit, S. \& Lal, R. (2010). Sphingomonas histidinilytica sp. nov., isolated from a hexachlorocyclohexane dumpsite. Int J Syst Evol Microbiol 60, 1038-1043.

Ohta, H., Hattori, R., Ushiba, Y., Mitsui, H., Ito, M., Watanabe, H., Tonosaki, A. \& Hattori, T. (2004). Sphingomonas oligophenolica sp. nov., a halo- and organo-sensitive oligotrophic bacterium from paddy soil that degrades phenolic acids at low concentrations. Int J Syst Evol Microbiol 54, 2185-2190.

Reasoner, D. J. \& Geldreich, E. E. (1985). A new medium for the enumeration and subculture of bacteria from potable water. Appl Environ Microbiol 49, 1-7.

Roh, S. W., Kim, K.-H., Nam, Y.-D., Chang, H.-W., Kim, M.-S., Oh, H.-M. \& Bae, J.-W. (2009). Sphingomonas aestuarii sp. nov., isolated from tidal flat sediment. Int J Syst Evol Microbiol 59, 1359-1363.

Sambrook, J., Fritsch, E. F. \& Maniatis, T. (1989). Molecular Cloning: a Laboratory Manual, 2nd edn. Cold Spring Harbor, NY: Cold Spring Harbor Laboratory.

Sasser, M. (1990). Identification of bacteria by gas chromatography of cellular fatty acids, MIDI Technical Note 101. Newark, DE: MIDI Inc.
Stolz, A., Busse, H.-J. \& Kämpfer, P. (2007). Pseudomonas knackmussii sp. nov. Int J Syst Evol Microbiol 57, 572-576.

Takeuchi, M., Hamana, K. \& Hiraishi, A. (2001). Proposal of the genus Sphingomonas sensu stricto and three new genera, Sphingobium, Novosphingobium and Sphingopyxis, on the basis of phylogenetic and chemotaxonomic analyses. Int J Syst Evol Microbiol 51, 1405-1417.

Thompson, J. D., Gibson, T. J., Plewniak, F., Jeanmougin, F. \& Higgins, D. G. (1997). The CLUSTAL_X windows interface: flexible strategies for multiple sequence alignment aided by quality analysis tools. Nucleic Acids Res 25, 4876-4882.

Wayne, L. G., Brenner, D. J., Colwell, R. R., Grimont, P. A. D., Kandler, O., Krichevsky, M. I., Moore, L. H., Moore, W. E. C., Murray, R. G. E. \& other authors (1987). International Committee on Systematic Bacteriology. Report of the ad hoc committee on reconciliation of approaches to bacterial systematics. Int J Syst Bacteriol 37, 463464.

Wu, C., Lu, X., Qin, M., Wang, Y. \& Ruan, J. (1989). Analysis of menaquinone compound in microbial cells by HPLC. Microbiology [English translation of Microbiology (Beijing)] 16, 176-178.

Xie, C.-H. \& Yokota, A. (2006). Sphingomonas azotifigens sp. nov., a nitrogen-fixing bacterium isolated from the roots of Oryza sativa. Int J Syst Evol Microbiol 56, 889-893.

Yabuuchi, E., Yano, I., Oyaizu, H., Hashimoto, Y., Ezaki, T. \& Yamamoto, H. (1990). Proposals of Sphingomonas paucimobilis gen. nov. and comb. nov., Sphingomonas parapaucimobilis sp. nov., Sphingomonas yanoikuyae sp. nov., Sphingomonas adhaesiva sp. nov., Sphingomonas capsulata comb. nov., and two genospecies of the genus Sphingomonas. Microbiol Immunol 34, 99-119.

Yabuuchi, E., Kosako, Y., Fujiwara, N., Naka, T., Matsunaga, I., Ogura, H. \& Kobayashi, K. (2002). Emendation of the genus Sphingomonas Yabuuchi et al., 1990 and junior objective synonymy of the species of three genera, Sphingobium, Novosphingobium and Sphingopyxis, in conjunction with Blastomonas ursincola. Int J Syst Evol Microbiol 52, 1485-1496.

Zhang, D.-C., Wang, H.-X., Liu, H.-C., Dong, X.-Z. \& Zhou, P.-J. (2006). Flavobacterum glaciei sp. nov., a novel psychrophilic bacterium isolated from the China No.1 glacier. Int J Syst Evol Microbiol 56, 2921-2925.

Zhang, J.-Y., Liu, X.-Y. \& Liu, S.-J. (2010). Sphingomonas changbaiensis sp. nov., isolated from forest soil in the northeast of China. Int J Syst Evol Microbiol 60, 790-795. 